\title{
Atlantis
}

Critical Studies in Gender, Culture \& Social Justice

Études critiques sur le genre, la culture, et la justice

\section{Gender and the Canadian Armed Forces: Does Change Mean Feminist Progress?}

\section{Maya Eichler}

Volume 41, Number 2, 2020

Gender and the Canadian Armed Forces

URI: https://id.erudit.org/iderudit/1076196ar

DOI: https://doi.org/10.7202/1076196ar

See table of contents

Publisher(s)

Mount Saint Vincent University

ISSN

1715-0698 (digital)

Explore this journal

Cite this document

Eichler, M. (2020). Gender and the Canadian Armed Forces: Does Change Mean Feminist Progress? Atlantis, 41(2), 3-8. https://doi.org/10.7202/1076196ar
Article abstract

An introduction to the special issue Gender and the Canadian Armed Forces: Does Change Mean Feminist Progress? It situates the special issue within the significant gendered changes that have occurred within the Canadian Armed Forces over the past two decades. The introduction highlights the importance of continued feminist critique of, and engagement with, the military to achieve feminist progress.
All Rights Reserved @ Maya Eichler, 2020

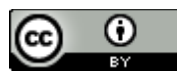

This document is protected by copyright law. Use of the services of Érudit (including reproduction) is subject to its terms and conditions, which can be viewed online.

https://apropos.erudit.org/en/users/policy-on-use/ 


\section{Gender and the Canadian Armed Forces: Does Change Mean Feminist Progress?}

Maya Eichler holds the Canada Research Chair in Social Innovation and Community Engagement and is an associate professor in Political and Canadian Studies and Women's Studies at Mount Saint Vincent University. She is the author of Militarizing Men: Gender, Conscription, and War in Post-Soviet Russia (Stanford University Press 2012) and the editor of Gender and Private Security in Global Politics (Oxford University Press 2015). Her current research focuses on gender integration and sexual violence in the Canadian Armed Forces, military-to-civilian transitions, and community stories of war and peace. Her articles have appeared in Critical Military Studies, Etudes internationales, Armed Forces and Society, Critical Studies on Security, Citizenship Studies, International Journal, Military Behavioral Health, and The Journal of Military, Veteran and Family Health. She is currently the GBA+ Convenor for the DND-MINDS funded Defence and Security Foresight Group.

Abstract: An introduction to the special issue Gender and the Canadian Armed Forces: Does Change Mean Feminist Progress? It situates the special issue within the significant gendered changes that have occurred within the Canadian Armed Forces over the past two decades. The introduction highlights the importance of continued feminist critique of, and engagement with, the military to achieve feminist progress.

Keywords: Canadian Armed Forces, change, gender, feminism, military, women
$\mathrm{M}$ ilitaries are an important site for feminist investigation because they are one of society's key institutions of gendered power. Militaries privilege and empower men and masculinities, reinforce gendered protection myths, and perpetuate discrimination and violence against women. Militaries also claim a large part of societal resources-resources that could be directed towards non-militarized security concerns that disproportionately impact women's lives, such as human and food security. While some feminists emphasize the importance of military service to women's full citizenship, most feminists are critical of, if not opposed to, militaries and militarism, seeing the end to war and militarism as part of broader feminist struggles for change. But in the early twenty-first century, feminists in Canada and globally need to grapple with a new reality-one in which states wage wars in the name of protecting women's rights, foreign policies are declared to be feminist, and militaries themselves are actively recruiting women and integrating gender perspectives into planning and operations (Eichler 2020).

Twenty years ago, Atlantis published a special collection of articles dedicated to feminist analyses of the military. "Women and the Canadian Military" (Gouliquer 2001) highlighted the many ways in which women had contributed to the Canadian Armed Forces (CAF), even as discriminatory policies and gender norms had limited their ability to participate. That special collection included articles on women's roles as soldiers and as partners of servicemen and servicewomen. With the current special issue presented here, we revisit the topic of women's involvement in the Canadian military by examining recent changes within militaries and in feminist scholarship on militaries. 


\section{Changing Context}

Much has changed within the CAF over the past twenty years, and it is therefore an opportune time to reconsider questions of feminist progress in relation to the Canadian military. Three distinct shifts have taken place that inform the contributions of this special issue. The first is the war in Afghanistan (2001-2014), the longest military engagement in Canadian history. The CAF opened combat occupations to women in 1989 as a result of a Human Rights Tribunal Decision, but it was Canada's more than decade-long military deployments to Afghanistan that changed the public's perception of women's role in war. With ten percent of deployed troops being women, Canada's war in Afghanistan led to a greater recognition of the contributions of servicewomen. The war brought the first death of a female combat soldier in Canadian history. But the death of Captain Nichola Goddard also highlighted the continuing unease in Canada's relationship to its servicewomen. Media reporting oscillated between contradictory portrayals of a military in which gender no longer mattered and a military that was eager to emphasize the apparent utility of military women in counter-insurgency warfare (Chapman and Eichler 2014). The war in Afghanistan also stood out as one of the first in Canadian history that was justified on the basis of protecting and promoting women's rights, a common gendered justification put forward in the Global War on Terror (see Hunt and Rygiel 2006).

The second significant shift we have seen in Canada is the military's public acknowledgement of military sexual violence as a systemic problem. While media reports had drawn attention to sexual harassment and sexual assault in the military since the 1990s, it was only in 2014-in response to another series of media reports-that the Chief of Defence staff ordered an external review into the matter. The External Review into Sexual Misconduct and Sexual Harassment in the CAF, known as the Deschamps Report and referenced in several of the contributions in this special issue, was released in 2015. It found that the military had a sexualized culture hostile towards female and lesbian, gay, bisexual, transgender, and queer/questioning members
(Deschamps 2015). The first external survey on sexual misconduct in the CAF was conducted in 2016 by Statistics Canada and confirmed the findings of the Deschamps Report. That survey found that four in five military members had reported "seeing, hearing or experiencing inappropriate sexual or discriminatory behaviour" in their workplace during the previous 12 months, and that more than one in four women in the Regular Force and close to one in three women in the Reserves have experienced sexual assault during their military service (Cotter 2016, 25). In response to the Deschamps Report, the military embarked on Operation HONOUR, a mission aimed at ending sexual misconduct in the CAF. Despite these efforts, the military continues to struggle with finding an effective way to address military sexual violence (Eichler 2019). Operation HONOUR has been recently reframed as an ongoing and long-term culture change strategy in recognition of its limited success so far (National Defence and CAF 2020).

The final notable shift has been the passage of United Nations Security Council Resolution (UNSCR) 1325 on Women, Peace and Security in 2000. Referred to as the Women, Peace and Security agenda, this resolution, together with its nine follow-up resolutions, deals with a host of issues related to the protection of women and girls during armed conflict and their participation in peacekeeping, conflict resolution, the prevention of conflict, and post-conflict recovery. As one of the non-permanent members of the United Nations Security Council at the time, Canada was at the forefront of global efforts to adopt UNSCR 1325 but was slow in its own implementation of the Women, Peace and Security agenda over the following decade. This trend was reversed under the first Trudeau government. In early 2017, the Chief of Defence Staff passed a directive that follows through on Canada's international commitments to gender mainstream its defence policy through UNSCR 1325 and its follow-up resolutions. The directive commits the military to apply a gender perspective and genderbased analysis "plus" (GBA+) to all CAF planning and operations (Chief of Defence Staff 2016a). As a result of this directive, most Department of National Defence (DND) employees and CAF members have 
completed GBA+ online training through the Department of Women and Gender Equality. The CAF has also established three Gender Advisor positions, has committed to having Gender Advisors on all military operations, and has created a Directorate for Integration of Gender Perspectives that works jointly with the DND Directorate for Gender, Diversity, and Inclusion (Eichler 2020).

The three shifts described here highlight some of the key changes we have seen in the CAF over the past two decades. They have taken place within the context of other noteworthy changes such as Canada's adoption of a feminist foreign policy (Woroniuk 2020), the implementation of a new defence policy that explicitly includes gender concerns (National Defence and CAF 2017), and many other initiatives such as the development of a CAF Diversity Strategy (Chief of Defence Staff 2016b). The last decade has also been one of immensely strong activism from current and former military members challenging the military's gender culture. Two class action law suits were settled in 2018 and 2019: the LGBT Purge Class Action and the CAF-DND Sexual Misconduct Class Action. Many of the significant changes we have seen within the CAF over the past few years would not have happened without the pressure of this legal activism.

\section{Contributions to this Special Issue}

What do these changes mean for feminist progress? What is their transformational potential? Does the increasing recognition of women, acknowledgement of military sexual violence, and adoption of gender perspectives by the Canadian military indicate feminist progress or a co-optation of women and feminism? These are the questions this special issue of Atlantis tackles. In doing so, the contributors take up the challenge put forward by British scholars Claire Duncanson and Rachel Woodward (2016). In their 2016 article "Regendering the Military: Theorizing Women's Military Participation," they argued that we need to consider and pay attention to the possibilities of transforming military institutions-both their masculinized ideals of soldiering and their primary purpose as agents of violence. They cautioned against assuming that militaries are necessarily and deterministically hypermasculine and violent.

This special issue showcases critical, feminist-informed research on the CAF by five emerging scholars. The first two contributions, by Victoria Tait and Vanessa Brown respectively, most directly engage with the argument put forward by Duncanson and Woodward (2016). Both Tait and Brown find that there are tentative signs of a regendering of the CAF, while both offer cautionary notes about its present limitations.

Tait's article, "Regendering the Canadian Armed Forces," examines how Canadian military personnel think about recent initiatives aimed at changing the military's gender culture-in particular the implementation of UNSCR 1325 and the use of Gender Advisors on deployments. Based on interviews with military personnel, Tait finds that servicemen's attitudes towards women and other military minority populations are changing for the better, while servicewomen themselves are more willing to embrace attributes stereotypically associated with femininity (and historically devalued in militaries) and champion the use of gender perspectives. Tait cautions us, though, that the results presented in her article may not reflect the CAF as a whole and that changing attitudes also run the risk of being framed in ways that construct Canada as more progressive and "civilized" compared to other countries, thus reproducing a racialized global hierarchy of states.

Brown's article, "Locating Feminist Progress in Professional Military Education," similarly finds seeds of change in the military's gender culture, but locates these in the introduction of feminist ideas into Professional Military Education. Based on interviews with officer students as well as teaching and other support staff in the Joint Command and Staff Programme at Canadian Forces College, Brown shows that Professional Military Education can be a mechanism through which Canadian military personnel achieve greater awareness and understanding about intersectional social inequalities within and beyond the military. Yet Brown also notes that, in their current form, initiatives to integrate gender perspectives and GBA+ 
in training and education are likely not sufficient to create culture change within the military. Significantly, though, she argues that feminist change within militaries can happen and that feminists should continue to engage with militaries.

The next three contributions, by Tammy George, Leigh Spanner, and Walter Callaghan, offer critical assessments of how far the CAF has come in terms of transformational change. George's article, "Troubling Diversity and Inclusion: Racialized Women's Experiences in the Canadian Armed Forces," outlines recent diversity and inclusion initiatives in the CAF and juxtaposes these initiatives with the lived experience of racialized women who have served in the military. As George shows through analysis of interview transcripts, the experiences of racialized servicewomen demonstrate the limits of current military diversity and inclusion initiatives and their neoliberal logic of governing racialized minority subjects. George warns that these initiatives create illusions of progress instead of meaningful change, and leave the work of inclusion up to individual racialized servicewomen rather than challenging the integral place of racism, sexism, heteronormativity, homophobia, and other intersecting forms of power in military culture.

In "The Strength Behind the Uniform: Acknowledging the Contributions of Military Families or Coopting Women's Labour?” Spanner details the changes to family policies and support services over the past two decades and the shift in the military's position from taking for granted spousal support to explicitly acknowledging it. But this shift, she argues, is informed by neoliberal ideas of self-reliance, resilience, and independence and a heteropatriarchal division of labour in support of the operational goals of the military. Military spouses, the majority of whom are civilian women, are instructed on how to care for an ill and injured spouse, ensure intimacy in their military marriage, and pursue personal growth in the midst of the demands of military life. In a similar vein to George's contribution, Spanner's article concludes that the military's explicit acknowledgement of the indispensable role of the military family cannot be read as a sign of feminist progress as it has, in fact, exacerbated the exploitation of today's military spouses.

Callaghan's article takes a critical look at the CAF's response to sexual misconduct in its ranks. As a veteran, veteran advocate, and ally to survivors of military sexual trauma, Callaghan is deeply embedded in the community he studies. He takes aim at the military's framing of the problem of military sexual misconduct, insisting that the military pay more attention to how servicemembers' reactions and responses to this problem are embedded in the military's sexist culture. Utilizing an existing taxonomy of sexism, he explores three archetypes of behaviour he has observed in his ethnographic research with veterans: (1) potential allyship with victims/survivors, (2) wilful blindness to the prevalence and harms of military sexual misconduct, and (3) a toxic and misogynistic response that denies the problem and blames victims/survivors. He concludes that in order to address sexual misconduct, the military will have to address the fact that toxic and wilfully blind responses towards instances of sexual misconduct are embedded within its culture and intimately linked to the self-perceptions and identities of military members.

The special issue is rounded off by a short story and a film review by established feminist scholars, some of whom have themselves served in the military. In "Khaki and Emerald Green," Nancy Taber tells the fictional story of Ruth, who serves in the CAF. Taber weaves together the many threads of her protagonist's life: her deployment to Afghanistan, her experience of military sexual trauma, and her role as a parent and military spouse. The story invites the reader to share in Ruth's pride, her disappointment and sense of institutional betrayal, and her search for closure and healing. Connecting with the story of another female impacted by war and militarization-a girl in the Ugandan civil war-brings Ruth one step closer to being able to share her own story publically.

The final piece is a review of The Fruit Machine by Lynne Gouliquer, Carmen Poulin, and the Psycho-Social Ethnography of the Common Place (P-SEC) Research Group at the University of New Brunswick. Directed by Sarah Fodey, The Fruit Machine is a 
groundbreaking documentary of Canada's LGBT Purge. The LGBT Purge was a decades-long government campaign, running from the 1950 s to the early 1990 s, that aimed to identify, investigate, harass, and remove "homosexuals" from the Canadian public service. While the authors of our review acknowledge the significant contribution of The Fruit Machine in making visible this part of Canadian history, they also offer critical reflection. They suggest, for example, that the documentary could have done more to connect the Purge campaign and the experiences of gender and sexual minorities in the military to an analysis of a military culture rooted in sexual violence, heteronormativity, femmenegativity, and hegemonic masculinity.

The cover image of this special issue has been contributed by Jessica Lynn Wiebe (see www.jessicalynnwiebe.com). Wiebe is a Canadian veteran who served in Afghanistan in 2008. After leaving the military, she embarked on a fine arts programme and graduated from the Nova Scotia College of Art and Design. She uses interdisciplinary art forms-including storytelling, performance, and painting-to make sense of her military experiences and the gendered politics of war and conflict more broadly. Creating dialogue between military and civilian actors, and challenging the worldviews of both, are central to her practice as an artist, and also reflect what we hope to achieve with this issue of Atlantis.

This special issue includes the voices of CAF servicemembers and veterans-both through the qualitative research presented and the perspectives of those contributors who are themselves former military members. This speaks to the feminist conviction that we must hear the voices of those most affected by, and embedded within, the world we seek to understand and change. Today's feminist scholarship goes beyond earlier feminist debates that were polarized between advocating for women's "right to fight" and opposing women's co-optation into militarism. Today's generation of feminist scholars is engaged in the daunting task of critiquing, and even opposing, militaries while also engaging with them more deeply than ever. This puts us in a precarious position. But only through feminist engagement with the military — by feminists inside and beyond the military-is there hope that the many changes we have seen over the past decades will lead to feminist progress. 


\section{References}

Chapman, Krystel, and Maya Eichler. 2014.

"Engendering Two Solitudes? Media Representations of Women in Combat in Quebec and the Rest of Canada." International Journal 69 (4): 594-611.

Chief of Defence Staff. 2016a. CDS Directive for Integrating UNSCR 1325 and Related Resolutions into CAF Planning and Operations. Directive. Ottawa: National Defence, January 29. http://www.forces.gc.ca/ assets/FORCES_Internet/docs/en/about-reportspubs-cds/cds-directive-unscr-1325-directive-cemdrcsnu-1325.pdf.

Chief of the Defence Staff. 2016b. Canadian Armed Forces Diversity Strategy. Action Plan. Ottawa: National Defence.

Cotter, Adam. 2016. Sexual Misconduct in the Canadian Armed Forces, 2016. Statistics Canada, November 28. http://www.statcan.gc.ca/pub/85-603x/85-603-x2016001-eng.pdf.

Deschamps, Marie. 2015. External Review into Sexual Misconduct and Sexual Harassment in the Canadian Armed Forces. Ottawa: External Review Authority, March 27. http://www.forces.gc.ca/assets/ FORCES_Internet/docs/en/caf-community-supportservices-harassment/era-final-report-(april-20-2015)eng.pdf.

Duncanson, Claire, and Rachel Woodward. 2016. "Regendering the Military: Theorizing Women's Military Participation.” Security Dialogue 47 (1): 3-21. https://doi.org/10.1177/0967010615614137.

Eichler, Maya. 2020. "How Gender Became a Defence Issue: A Feminist Perspective on Canadian Military and Defence Policy." In Turbulent Times, Transformational Possibilities? Gender and Politics Today and Tomorrow, edited by Fiona MacDonald and Alexandra Dobrowolsky, 141-58. Toronto: University of Toronto Press.
Eichler, Maya. 2019. "Military Sexual Violence in Canada." In Dis/Consent: Perspectives on Sexual Violence and Consensuality, edited by KellyAnne Malinen, 75-82. Halifax/Winnipeg: Fernwood Publishing.

Gouliquer, Lynne, ed. 2001. "Special Collection: Women and the Canadian Military." Atlantis: Critical Studies in Gender, Culture, and Social Justice 26 (1): 31-76.

Hunt, Krista, and Kim Rygiel, eds. 2006. (En) Gendering the War on Terror: War Stories and Camouflaged Politics. London: Ashgate.

National Defence and Canadian Armed Forces. 2017. Strong, Secure, Engaged: Canada's Defence Policy. Ottawa: Government of Canada. http:// dgpaapp.forces.gc.ca/en/canada-defence-policy/docs/ canada-defence-policy-report.pdf.

National Defence and Canadian Armed Forces. 2020. The Path to Dignity and Respect: The Canadian Armed Forces Sexual Misconduct Response Strategy. Ottawa: Government of Canada. https://www.canada.ca/ content/dam/dnd-mdn/documents/reports/2020/thepath-to-dignity-and-respect-en.pdf.

United Nations Security Council. 2000. Resolution 1325 (2000). October 31. UN doc. no. S/RES/1325.

Woroniuk, Beth. 2020. "Canada's Feminist Foreign Policy: New WPSN-C Blog Series.” December 7. https://wpsn-canada.org/2020/12/07/canadasfeminist-foreign-policy-new-wpsn-c-blog-series/ 